\title{
Calcium/Calmodulin-activated Phosphodiesterase Expressed in Olfactory Receptor Neurons
}

\author{
Felice F. Borisy, ${ }^{1}$ Gabriele V. Ronnett, ${ }^{1,2}$ Anne M. Cunningham, ${ }^{3}$ Dawn Juilfs, ${ }^{4}$ Joseph Beavo, ${ }^{4}$ and Solomon $\mathrm{H}$. \\ Snyder ${ }^{1}$ \\ 'Departments of Neuroscience, Pharmacology and Molecular Sciences, and Psychiatry and Behavioral Sciences, \\ 2Department of Neurology, and 'Department of Molecular Biology and Genetics, The Howard Hughes Medical Institute, \\ Johns Hopkins Medical Institutions, Baltimore, Maryland 21205 and ${ }^{4}$ Department of Pharmacology, University of \\ Washington, Seattle, Washington 98195
}

\begin{abstract}
We show that calmodulin-dependent phosphodiesterase (CAM-PDE) is selectively expressed in mature olfactory receptor neurons within the olfactory mucosa. Immunocytochemical staining reveals neuronal immunoreactivity that is most pronounced within cilia, dendritic knobs, and axon bundles. Neither sustentacular cells nor basal cells display immunoreactivity. The extent of loss of neuronal immunoreactivity following bulbectomy resembles loss of the neuronal population. High-affinity CAM-PDE activity in olfactory cilia is fivefold greater than in brain, when assayed at low micromolar CAMP. This activity is depleted in turbinates following bulbectomy. Olfactory mucosal PDE activity is composed of a minimum of two major forms. In the absence of $\mathrm{Ca}^{2+}$, rolipram-sensitive PDE comprises $65 \%$ of total activity. Following stimulation by $\mathrm{Ca}^{2+}$, CAM-PDE activity is elevated sixfold to become the predominant form, thereby increasing total activity $300 \%$, with half-maximal effect at $1 \mu \mathrm{M} \mathrm{Ca}^{2+}$. We propose that $\mathrm{Ca}^{2+}$ stimulation of CAM-PDE may be necessary for termination of olfactory signals.
\end{abstract}

The initial events of olfaction occur in the ciliary processes of olfactory receptor neurons. These odorant-sensitive neurons are asymmetric bipolar cells that rest on a basal layer of proliferative stem cells and are intercalated between supportive sustentacular cells. Each neuron sends a long axon inward through the cribriform plate to synapse in the olfactory bulb, and an apical dendrite outward into the mucosal layer. This dendrite terminates in a knob from which originate the chemoreceptive cilia.

Cyclic nucleotides, especially cAMP, appear to play a crucial role in olfactory signal transduction. They mediate the activation of an odor-induced depolarization (Firestein and Werblin, 1989; Firestein et al., 1991), most likely by directly gating a channel in olfactory cilia (Nakamura and Gold, 1987; Frings and Lindemann, 1991; Lowe and Gold, 1991). Odorants stimulate adenylyl cyclase activity of olfactory cilia (Pace et al., 1985;

Received July 11, 1991; revised Oct. 1, 1991; accepted Oct. 10, 1991.

This work was supported by USPHS Grant DA-00266, USPHS Research Scientist Award DA-00074 to S.H.S., a grant from International Flavors and Fragrances, USPHS Grant NS-01231 to G.V.R., and a grant from the Medical Foundation, The University of Sydney, NSW, Australia to A.M.C.

Correspondence should be addressed to Solomon H. Snyder, M.D., Johns Hopkins University School of Medicine, Department of Neuroscience, 725 North Wolfe Street, Baltimore, MD 21205.

Copyright (C) 1992 Society for Neuroscience $0270-6474 / 92 / 120915-09 \$ 05.00 / 0$
Sklar et al., 1986; Breer et al., 1990) and primary cultures of olfactory neurons (Ronnett et al., 1991a,b), effects that can occur rapidly and at low concentrations of odorants (Boekhoff et al., 1990; Ronnett et al., 1991b). The rapid decline in cAMP levels suggests an important regulatory role for phosphodiesterase (PDE). PDE activity has been previously demonstrated in cilia (Anholt and Rivers, 1990) and olfactory neurons (Margolis, 1977; Firestein et al., 1991), but the enzyme forms present have not yet been identified.

Evidence for a role of $\mathrm{Ca}^{2+}$ in olfaction suggests that a $\mathrm{Ca}^{2+}$ / calmodulin PDE (CAM-PDE) activity might be relevant. For instancc, odorants stimulate the influx of $\mathrm{Ca}^{2+}$ into olfactory neurons (Restrepo et al., 1990), calmodulin antagonists alter the electro-olfactogram (Winegar et al., 1988), and odorants potently stimulate inositol 1,4,5-trisphosphate (IP $)$ formation, which is associated with the release of sequestered $\mathrm{Ca}^{2+}$ (Boekhoff et al., 1990; Wood et al., 1990). Moreover, the adenylyl cyclase whose activity is enhanced by odorants in primary olfactory neuronal cultures is absolutely dependent upon $\mathrm{Ca}^{2+}$ (Ronnett et al., 1991b), while ciliary adenylyl cyclase is stimulated by $\mathrm{Ca}^{2+} /$ calmodulin (Anholt and Rivers, 1990).

At least five separate subtypes of PDE have been distinguished on the basis of substrate affinity, activation or inhibition by cGMP, effects of inhibitors, and the influence of $\mathrm{Ca}^{2+}$ and calmodulin (Thompson et al., 1972; Beavo, 1988; Kincaid and Manganiello, 1988). CAM-PDE is selectively stimulated by $\mathrm{Ca}^{2+}$ and calmodulin (Teo and Wang, 1973; Sharma and Wang, 1986). One form of PDE has high affinity for cAMP and is selectively inhibited by the antidepressant drug rolipram (Thompson et al., 1979; Wachtel, 1983; Nemoz et al., 1989). Another form with high affinity for cAMP is activated by cGMP (Beavo et al., 1971; Martins et al., 1982; Yamamoto et al., 1983), while a third form selective for cAMP is inhibited by cGMP (Weber and Appleman, 1982; Harrison et al., 1986; Simmons and Hartzell, 1988). The retina possesses a $\mathrm{PDE}$ with considerable selectivity for cGMP (Miki et al., 1973).

In the present study, we identify and localize a CAM-PDE in rats associated with ORNs.

\section{Materials and Methods}

Materials. $2,8-{ }^{3} \mathrm{H}$-cAMP $(44.5 \mathrm{Ci} / \mathrm{mmol})$ and $8,5-{ }^{3} \mathrm{H}-\mathrm{cGMP}(36.9 \mathrm{Ci} /$ $\mathrm{mmol}$ ) were obtained from NEN-Du Pont, Boston, MA. Rolipram was supplied by Schering AG, Berlin, Germany. Ro20-1724 was purchased from Biomol Research Laboratories (Plymouth Meeting, PA). Denbufylline was supplied by Smith-Kline Beecham Pharmaceuticals (Betch- 
worth, England). Milrinone was supplied by Sterling-Winthrop Research Institute (Rensselaer, NY). CL-930 was supplied by Warner-Lambert/ Parke-Davis (Anne Arbor, MI). N-(6-aminohexyl)-5-chloro-1-naphthalenesulfonamide hydrochloride (W-7) was purchased from GIBCO BRL (Gaithersburg, MD). Calmodulin, cAMP, cGMP, 5'-nucleotidase, Staph $A$, and all detergents and buffers were purchased from Sigma Chemical Company (St. Louis, MO), unless otherwise mentioned.

Immunohistochemistry. Adult male rats (150-200 gm) were anesthetized with sodium pentobarbital $(45 \mathrm{mg} / \mathrm{kg}$, i.p.) (Steris Laboratories, Phoenix, AZ) and perfused transcardially with phosphate-buffered saline (PBS) followed by 4\% paraformaldehyde (PFA) in PBS. Brain and olfactory tissues were dissected and postfixed $1 \mathrm{hr}$ in 4\% PFA and then sunk in $15 \%(\mathrm{w} / \mathrm{v})$ sucrose overnight. Blocks were embedded in TissueTek (Miles, Elkhart, IN), stored at $-70^{\circ} \mathrm{C}$ until use and then sectioned in a cryostat at $12 \mu \mathrm{m}$.

Staining was carricd out using a modification of the method described by Ronnett et al. (1991a). Brain and olfactory tissue sections were rinsed three times in PBS with all subsequent rinses performed identically, and then permeabilized for $30 \mathrm{~min}$ in $0.5 \%(\mathrm{w} / \mathrm{v})$ saponin in PBS or $0.1 \%$ $(w / v)$ Triton $X-100$ in PBS, respectively. Slides were rinsed and incubated $1 \mathrm{hr}$ in $10 \%(\mathrm{v} / \mathrm{v})$ normal goat serum (NGS) (Jackson Labs, Westgrove, PA) or $10 \%(\mathrm{v} / \mathrm{v})$ normal donkey serum (NDS) (Jackson Labs, Westgrove, PA), as appropriate to the secondary antibody, in PBS containing $1 \%(\mathrm{w} / \mathrm{v})$ bovine serum albumin (BSA). Following removal of the block, slides were incubated with primary antibody made up in PBS containing $0.5 \%(\mathrm{w} / \mathrm{v}) \mathrm{BSA}$ and $2 \%(\mathrm{v} / \mathrm{v}) \mathrm{NGS}$ or NDS as appropriate. Slides were rinsed and incubated $25 \mathrm{~min}$ in PBS containing $0.3 \%(\mathrm{v} / \mathrm{v})$ hydrogen peroxide to quench endogenous peroxidase. Slides were rinsed again and then blocked in 5\% (v/v) NGS or NDS in PBS containing $0.5 \%$ BSA. After block removal, slides were incubated $45 \mathrm{~min}$ with the appropriate biotinylated secondary antibody in PBS containing $0.5 \%$ $(\mathrm{w} / \mathrm{v})$ BSA. Slides were rinsed, blocked $5 \mathrm{~min}$ in PBS containing $0.5 \%$ $(\mathrm{w} / \mathrm{v}) \mathrm{BSA}$, and incubated $30 \mathrm{~min}$ with $2 \mu \mathrm{g} / \mathrm{ml}$ peroxidase-conjugated streptavidin (Jackson Labs, Westgrove, PA). Slides were rinsed in PBS and then exposed 5 min to the chromagen 3,3-diaminobenzidine tetrahydrochloride (GIBCO BRL). Slides were dehydrated with progressive ethanol gradations followed by xylene, and coverslipped.

Antisera were used as follows: mouse monoclonal antibody (MAb) ACC-A4C 3 against $\mathrm{Ca}^{2+}$ /calmodulin-dependent phosphodiesterase (CAM-PDE) (Hansen and Beavo, 1986) at 1:250 dilution; affinity-purified sheep polyclonal antibody to calmodulin (Polysciences, Inc., Warrington, PA) at 1:10 dilution; goat anti-mouse IgG biotinylated secondary antibody (Jackson Labs) at 1:500 dilution; donkey anti-sheep biotinylated secondary antibody (Jackson Labs) at 1:500 dilution.

Specificity of the antibody reaction was established in several ways. Staining was negative when nonimmune ascites fluid was used in place of primary antibody. Similarly, no staining was obtained with only NGS or NDS. The ability of MAb ACC-A4C3 to immunoprecipitate PDE activity when coupled to formalin-fixed Staph $A$ was examined using the method of Hansen and Beavo (1986). Antibody-conjugated Staph A and Staph A controls were incubated with soluble or microsomal tissue fractions overnight and then centrifuged $3 \mathrm{~min}$ at $10,000 \times \mathrm{g}$. After extensive washing, the pellets were assayed for PDE activity. In both cases, the antibody precipitated threefold more PDE activity than Staph A alone. Precipitated PDE activity was doubled in the presence of $\mathrm{Ca}^{2+}$ and calmodulin.

Tissue preparation. Tissue was prepared either as cilia, using the method of Sklar et al. (1986), or as homogenates or subcellular fractions of olfactory turbinates or cerebral cortex. Rats were anesthetized with carbon dioxide, decapitated, and tissue dissected. Nasal turbinates were dissected intact and consisted of the entire olfactory mucosa, including endothelial tissue, olfactory epithelium, and overlying mucous. Tissue was immediately placed on ice in BHB buffer, which contained $50 \mathrm{~mm}$ $N, N$-bis-(2-hydroxyethyl)-2-aminoethanesulfonic acid (BES) (Calbiochem, La Jolla, CA), 0.1 M EGTA, $0.08 \mathrm{mg} / \mathrm{ml}$ dithiothreitol (DTT), $0.1 \mathrm{mg} / \mathrm{ml}$ phenylmethylsulfonyl fluoride (PMSF), $0.5 \mu \mathrm{g} / \mathrm{ml}$ antipain, $1 \mu \mathrm{g} / \mathrm{ml}$ leupeptin, $1 \mu \mathrm{g} / \mathrm{ml}$ aprotinin, $0.6 \mu \mathrm{g} / \mathrm{ml}$ chymostatin, $0.6 \mu \mathrm{g} /$ $\mathrm{ml}$ pepstatin, $0.06 \%$ dimethyl sulfoxide, and $0.1 \%$ ethanol, and homogenized 15 times up and down in a glass-Tefion homogenizer at setting 3.3 of the Wheaton overhead stirrer (Millville, NJ). For fractionation, tissue was first centrifuged at $500 \times g$ for $5 \mathrm{~min}$ in a Sorvall RC $2 B$ superspeed refrigerated centrifuge (Du Pont, Wilmington, DE). The crude particulate $\left(P_{1}\right)$ pellet was discarded and the supernatant $\left(S_{1}\right)$ centrifuged $20 \mathrm{~min}$ at $28,000 \times \mathrm{g}$. The resultant pellet $\left(\mathrm{P}_{2}\right)$ was washed in $\mathrm{BHB}$, centrifuged, resuspended in $5 \mathrm{ml} \mathrm{BHB}$, and designated the membrane fraction. The supernatant $\left(S_{2}\right)$ was centrifuged $50 \mathrm{~min}$ at $230,000 \times g$ in Beckman L8-M ultracentrifuge (Fullerton, CA). The pellet $\left(\mathrm{P}_{3}\right)$ was washed in $\mathrm{BHB}$, recentrifuged in an ultracentrifuge, and resuspended in $2 \mathrm{ml}$ of $\mathrm{BHB}$ as the microsomal fraction. The supernatant $\left(S_{3}\right)$ was saved as the soluble fraction and visually inspected for absence of cloudiness or lipid droplets. In all cases, protein was assayed by the Bradford method using Coomassie protein assay reagent (Pierce, Rockford, IL) and BSA as standard.

$P D E$. PDE assays employed the method of Thompson et al. (1972) as modified by Bauer and Schwabe (1980), with standard reaction mixture adapted from Kincaid and Maganiello (1988). Before use, ${ }^{3} \mathrm{H}$-cAMP was purified over QAE-Sephadex (Pharmacia, Piscataway, NJ). Reaction mixture $(200 \mu \mathrm{l})$ containing $60,000-80,000 \mathrm{cpm}{ }^{3} \mathrm{H}-\mathrm{cAMP}$ was added to test tubes and prewarmed to $37^{\circ} \mathrm{C}$. Tissue was warmed to $37^{\circ} \mathrm{C}$, and $100 \mu \mathrm{l}$ aliquots containing 1-2 $\mu \mathrm{g}$ of protein were added to initiate the assay, which was conducted for $20 \mathrm{~min}$ at $37^{\circ} \mathrm{C}$. Final concentrations in the incubation mixture were $50 \mathrm{~mm}$ BES, $5 \mathrm{mM} \mathrm{MgCl}, 0.2 \mathrm{mg} / \mathrm{ml}$ BSA, 0.78-200 $\mu \mathrm{M}$ unlabeled cAMP, and 0.1 mM EGTA. For experiments at $100 \mu \mathrm{M}$ free $\mathrm{Ca}^{2+}$, the reaction mix included $0.2 \mathrm{mM} \mathrm{CaCl}_{2}$ and $50 \mathrm{~nm}$ calmodulin where appropriate. Low $\mathrm{Ca}^{2+}$ conditions were achieved by addition of $2.0 \mathrm{~mm}$ EGTA. $\mathrm{Ca}^{2+}$ levels were measured against standards using a conductivity meter and $\mathrm{Ca}^{2+}$ electrode (Biomedical Instrumentation Group, Philadelphia, PA). Following incubation, reactions were stopped by boiling for $1.5 \mathrm{~min}$ and cooling on ice, whereupon $100 \mu$ laliquots of $5^{\prime}$-nucleotidase $(10 \mathrm{U} / \mathrm{ml}$ in $0.1 \mathrm{M}$ Tris, $\mathrm{pH} 8.1$ ) were added and samples incubated for $30 \mathrm{~min}$ at $37^{\circ} \mathrm{C}$. Incubation mixtures were applied to QAE-Sephadex columns preequilibrated with $30 \mathrm{~mm}$ ammonium formate, with flow through and eluate from two $1 \mathrm{ml}$ washes collected in plastic scintillation vials. Ten milliliters of formula 963 (Du Pont, Wilmington, DE) were added, and radioactivity was assessed in Beckman LS 3801 counter (Irvine, CA). Assays of cGMP PDE were performed similarly, except that cGMP was used in place of cAMP and columns were eluted with $3 \mathrm{ml}$ wash volume.

Bulbectomy. Destruction of the olfactory bulb causes retrograde degeneration of olfactory receptor neurons in the olfactory mucosa (Margolis et al., 1974). Bulbectomies were performed unilaterally permitting comparison of normal and denervated sides. Adult male rats, 150-200 $\mathrm{gm}$, were anesthetized with chloral hydrate $(0.5 \mathrm{~g} / \mathrm{kg}, \mathrm{i} . \mathrm{p}$.) and placed in a stereotaxic head holder. A single $2 \mathrm{~cm}$ midline incision was made starting midway between the eyes. The dura on the right side was scraped to bare the bone. A hole was drilled through the bone directly above the olfactory bulb. A narrow glass pipette was placed in the hole and suction was gently applied. In a successful bulbectomy, the bulb could bc seen as a white mass during aspiration. After reaching bone, aspiration was complete. The hole was packed with Gelfoam and the skin was closed with surgical staples. Rats were kept warm while recovering, allowed to awaken naturally, and then returned to animal holding facilities until needed $10-11$ d later.

Cell culture. Primary cultures of olfactory receptor neurons were prepared as described previously (Ronnett et al., 1991a).

\section{Results}

\section{Biochemical characterization of PDE activity in olfactory}

tissue

In initial experiments, we explored the biochemical properties of PDE activity in homogenates of olfactory mucosa (Table 1). Using $1 \mu \mathrm{M}$ CAMP or $1 \mu \mathrm{M}$ cGMP in the presence of $100 \mu \mathrm{M}$ $\mathrm{Ca}^{2+}$, basal PDE activity in mucosal homogenates is threefold higher than with $100 \mu \mathrm{M}$ EGTA. Calmodulin further enhances the stimulation of enzyme activity by $\mathrm{Ca}^{2+}$, although to a greater extent in cilia than in mucosal homogenates.

Selective inhibitors of PDE were used to distinguish isoforms. Hydrolysis of both cAMP and cGMP in olfactory mucosa and cilia was assayed under $\mathrm{Ca}^{2+}$ chelating conditions or in the presence of $100 \mu \mathrm{M} \mathrm{Ca}{ }^{2+}$ (Fig. 1). When PDE activity in olfactory mucosa was assayed in the presence of $100 \mu \mathrm{M}$ EGTA and no added $\mathrm{Ca}^{2+}$ (Fig. 1A,B), $10 \mu \mathrm{M}$ rolipram, $10 \mu \mathrm{M}$ Ro20-1724, and $10 \mu \mathrm{M}$ denbufylline inhibited cAMP hydrolysis by $57 \%, 55 \%$, and $65 \%$, respectively. Neither $10 \mu \mathrm{M}$ rolipram nor $10 \mu \mathrm{M}$ Ro20- 

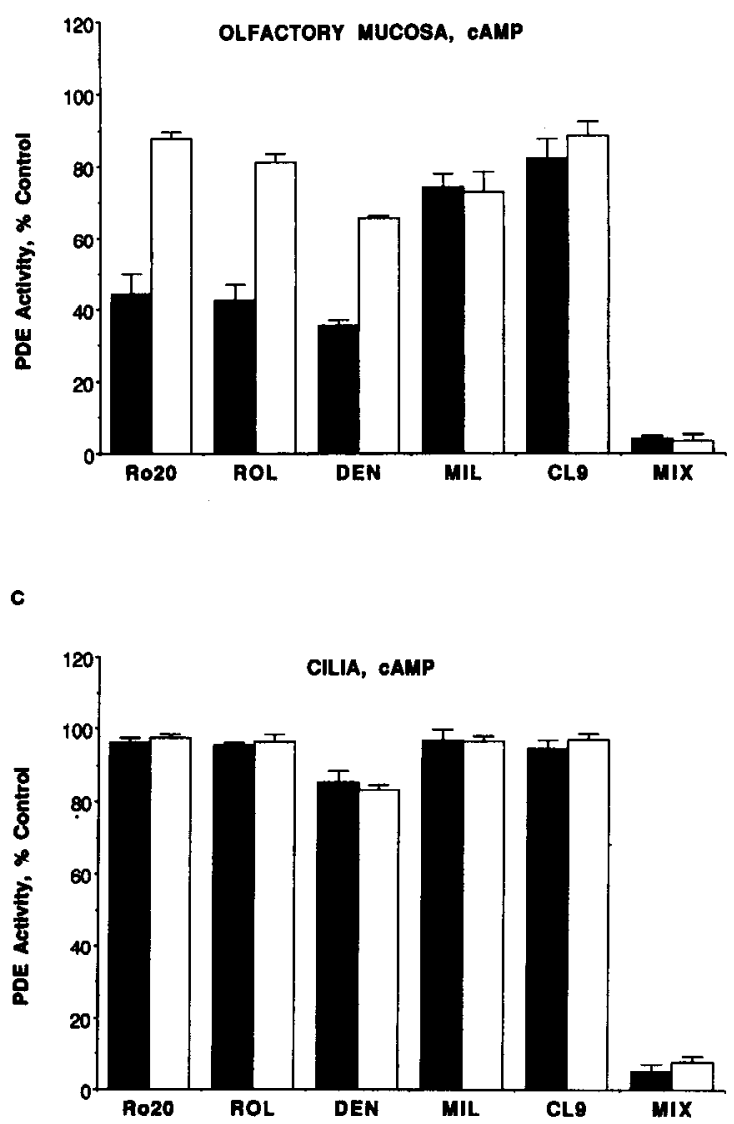

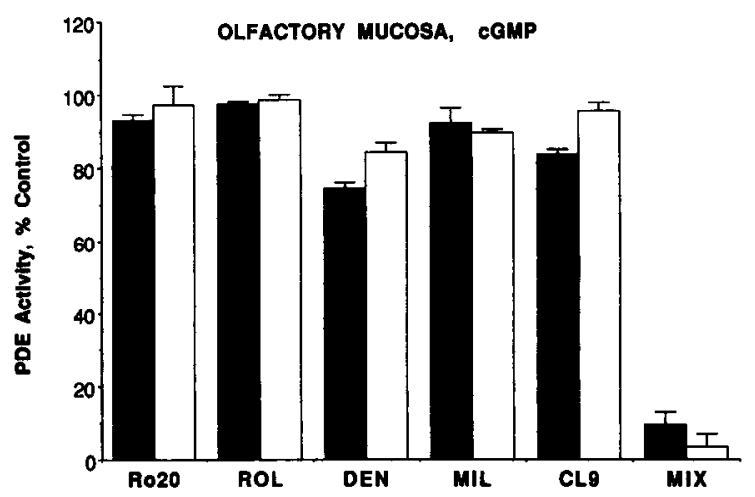

D

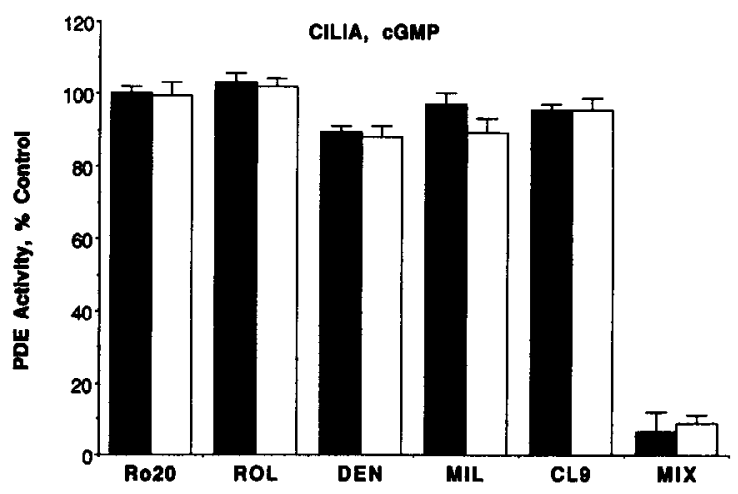

Figure 1. Effect of selective pharmacological agents on phosphodiesterase of olfactory turbinates and cilia. PDE activity in homogenates of olfactory turbinates was assayed using $1 \mu \mathrm{M}$ cAMP or $1 \mu \mathrm{M}$ CGMP as substrate as described in Materials and Methods. MIX was made initially as 500 mM stock in $0.1 \mathrm{M} \mathrm{NaOH}$ and used at 1:1000 dilution at $500 \mu \mathrm{M}$ final concentration. All other inhibitors were made initially as $10 \mathrm{~mm}$ stocks in $60 \%$ EtOH and used at 1:1000 dilution at $10 \mu \mathrm{M}$ final concentration. Final ethanol concentration was $0.06 \%$. Assays were performed with $100 \mu \mathrm{M}$ Ca ${ }^{2+}$ (open bars) or with $100 \mu \mathrm{M}$ EGTA (solid bars). Abbreviations: Ro20, Ro20-1724; ROL, rolipram; DEN, denbufylline; $M I L$, milrinone; CL9, CL930; $M I X, 1$-methyl-3-isobutyl xanthine. Error bars indicate SEM. A, Olfactory mucosa, cAMP PDE activity, assayed at $1 \mu \mathrm{M}$ cAMP. Data are means of three experiments performed in duplicate. $B$, Olfactory mucosa, cGMP PDE activity, assayed at $1 \mu \mathrm{M}$ cGMP. Data are means of two experiments performed in duplicale. $C$, Olfactory cilia, cAMP PDE activity, assayed at $1 \mu \mathrm{M}$ cAMP. Data are means of four experiments performed in duplicate. $D$, Olfactory cilia, cGMP PDE activity, assayed at $1 \mu \mathrm{M}$ cGMP. Data are means of two experiments performed in duplicate.

1724 inhibited cGMP hydrolysis, while $10 \mu \mathrm{M}$ denbufylline inhibited cGMP hydrolysis only about $25 \%$. These three drugs have been reported to inhibit selectively the high-affinity cAMPselective form of PDE (Epstein et al., 1982; Wachtel, 1983; Nicholson et al., 1989). The cardiotonic drugs milrinone (10 $\mu \mathrm{M})$ and $\mathrm{Cl} 930(10 \mu \mathrm{M})$, selective for cGMP-inhibited PDE (Harrison et al., 1986; Kincaid and Manganiello, 1988), reduced PDE activity about $20 \%$ whether in the presence of $100 \mu \mathrm{M}$
EGTA or with $100 \mu \mathrm{M} \mathrm{Ca}^{2+}$. In cilia (Fig. $1 C, D$ ), neither rolipram $(10 \mu \mathrm{M})$ nor Ro20-1724 (10 $\mu \mathrm{M})$ inhibited PDE, whether assayed in the presence or absence of $\mathrm{Ca}^{2+}$. Denbufylline $(10 \mu \mathrm{M})$ inhibited both ciliary CAMP and cGMP PDE about $15 \%$ in the presence or absence of $\mathrm{Ca}^{2+}$. Less than $10 \%$ inhibition occurred with $10 \mu \mathrm{M}$ milrinone or $10 \mu \mathrm{M}$ Cl-930 in cilia regardless of assay conditions.

We also examined the effect of $1 \mu \mathrm{M}$ cGMP on cAMP PDE

Table 1. Effects of $\mathrm{Ca}^{2+}$ and calmodulin on olfactory PDE activity

\begin{tabular}{|c|c|c|c|c|}
\hline & \multicolumn{2}{|l|}{ Cilia } & \multicolumn{2}{|c|}{ Olfactory mucosa } \\
\hline & cAMP & cGMP & cAMP & cGMP \\
\hline Control & $1.8 \pm 0.2$ & $1.5 \pm 0.2(5)$ & $0.42 \pm 0.12(4)$ & $0.20 \pm 0.05(4)$ \\
\hline $100 \mu \mathrm{M} \mathrm{Ca}^{2+}$ & $3.1 \pm 0.04(4)$ & $2.4 \pm 0.1(3)$ & $1.3 \pm 0.5$ & $0.62 \pm 0.15(3)$ \\
\hline $100 \mu \mathrm{M} \mathrm{Ca}^{2+}$ and & & & & \\
\hline 50 nM calmodulin & $5.7 \pm 0.6$ & $4.3 \pm 0.5(5)$ & $1.4 \pm 0.5$ & $0.79 \pm 0.15(4)$ \\
\hline
\end{tabular}

Data are PDE specific activity ( $\mathrm{nmol} / \mathrm{mg} / \mathrm{min}$ ) in cilia and homogenates of olfactory mucosa determined as described in Materials and Methods using $1 \mu \mathrm{M}$ cAMP or $1 \mu \mathrm{M}$ cGMP as substrate. Control conditions were assayed in the presence of $100 \mu \mathrm{M}$ EGTA. Where appropriate, $200 \mu \mathrm{M} \mathrm{Ca}{ }^{2+}$ was added alone or in combination with 50 nM calmodulin. Results are expressed as mean \pm SEM of $n$ independent experiments performed in duplicate, with $n$ indicated in parentheses. 
A

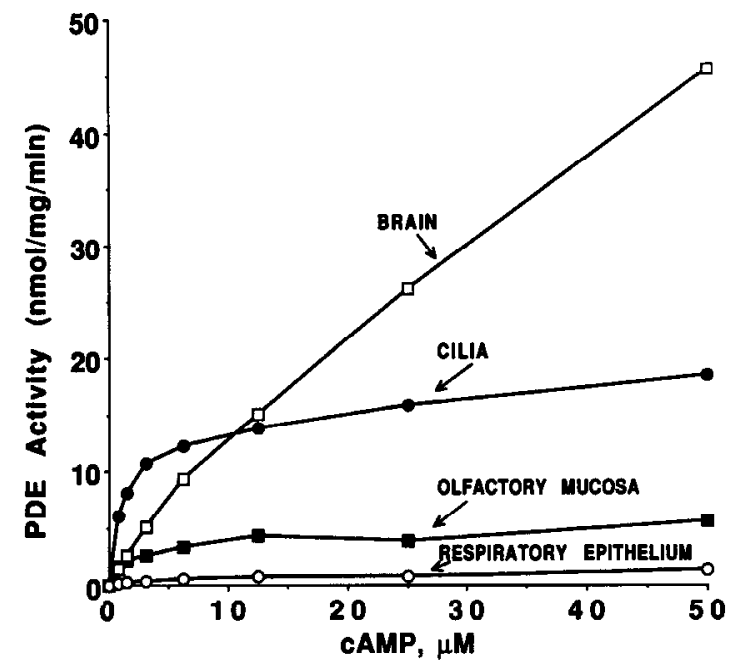

B

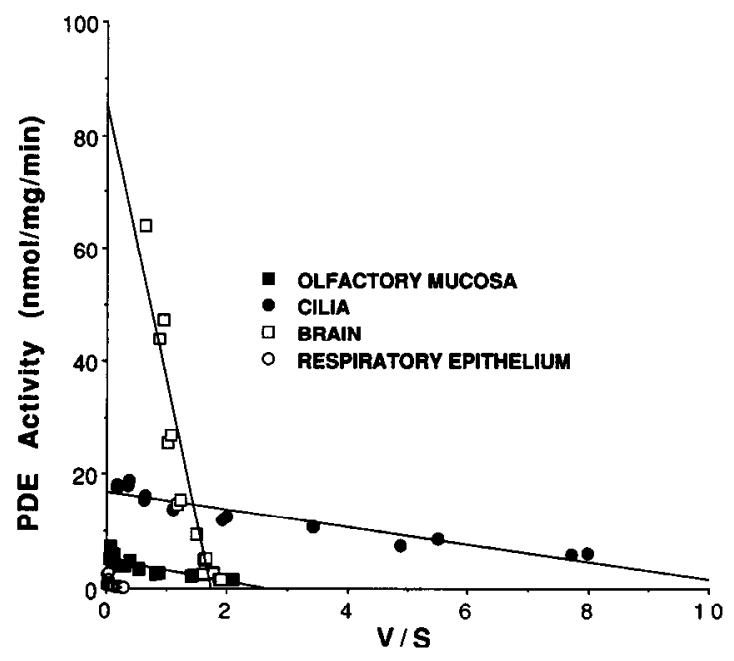

Figure 2. Comparison of PDE activities in olfactory cilia and homogenates of olfactory epithelium, respiratory epithelium, and cerebral cortex. $A$, Direct plot of enzyme activity versus cAMP concentration for olfactory mucosa, cilia, cerebral cortex, and respiratory epithelium. $B$, EadieHofstee analysis of enzyme activity ( $\mathrm{nmol} / \mathrm{mg} / \mathrm{min}$ ) versus activity divided by substrate concentration ( $\mu \mathrm{M})$. This experiment is representative of three experiments performed in duplicate.

activity. In both cilia and olfactory mucosa, cGMP stimulated cAMP hydrolysis to a limited extent, with a maximial 20-30\% enhancement at $10 \mu \mathrm{M}$ cAMP, in the presence of $100 \mu \mathrm{M}$ EGTA. This effect diminished markedly when $\mathrm{Ca}^{2+}$ and calmodulin were added, suggesting that cGMP-stimulated PDE is much less abundant than CAM-PDE.

These results suggest the presence of at least three forms of PDE in the olfactory mucosa, the two predominant ones being CAM-PDE and the rolipram-inhibitable PDE with high affinity for CAMP. PDE forms regulated by CGMP may be present to a lesser extent. In washed cilia, CAM-PDE appeared to be the predominant PDE.

We examined PDE activity with a wide range of cAMP concentrations in olfactory cilia, olfactory mucosa, respiratory epithelium, and brain homogenates (Fig. 2, Table 2). Olfactory cilia displayed the highest affinity for CAMP, as is evidenced in a direct plot of enzyme activity versus cAMP concentration (Fig. $2 A$ ) as well as in an Eadie-Hofstee analysis (Fig. $2 B$ ). By contrast, the highest maximal velocity occurred in brain tissue, with a $V_{\max }$ more than five times that of cilia. At low micromolar concentrations of CAMP, on the other hand, ciliary PDE activity was three to five times greater than in the brain. Maximal enzyme activity in olfactory mucosa was more than double that of respiratory epithelium. The presence of multiple enzymes with similar $K_{m}$ values is suggested by the slight curvatures of the Eadie-Hofstee plots. In studies of primary cultures of olfactory receptor neurons, which possess odorant-stimulated adenylyl cyclase activity (Ronnett et al., 1991b), the apparent $K_{m}$ for cAMP was $2.2 \mu \mathrm{M}$, about the same as in olfactory mucosa, while the $V_{\max }$ was $1.25 \mathrm{nmol} / \mathrm{mg} / \mathrm{min}$, similar to that of respiratory epithelium.

$\mathrm{Ca}^{2+}$ and calmodulin produced their greatest stimulation of PDE activity at low $(1 \mu \mathrm{M})$ cAMP levels with $3.5-4.0$-fold enhancement in olfactory epithelium, cilia, and brain and somewhat lesser stimulation in respiratory epithelium and primary olfactory neuronal cultures. Unlike the low-affinity brain CAMPDE, which had a $K_{m}$ of approximately $40 \mu \mathrm{M}$, olfactory CAMPDE appeared to be a high-affinity enzyme, with a $K_{m}$ of 1.4 $\mu \mathrm{M}$ in cilia. These results suggest that the olfactory CAM-PDE may be a different enzyme than that found in brain.

PDE activity in cilia was markedly stimulated by calmodulin (Fig. 3). At $1 \mu \mathrm{M}$ cAMP, half-maximal stimulation by calmodulin is apparent at $10 \mathrm{~nm}$. The calmodulin antagonist W-7 substantially reduced stimulation by calmodulin, while raising the concentration of calmodulin from $0.1 \mathrm{nM}$ to $1 \mu \mathrm{M}$ progressively augmented both cAMP and cGMP PDE activity, consis-

Table 2. Kinetic constants of PDE activity in nasal and brain tissue

\begin{tabular}{lcccc} 
& $\begin{array}{l}\text { Olfactory } \\
\text { mucosa }\end{array}$ & $\begin{array}{l}\text { Olfactory } \\
\text { cilia }\end{array}$ & $\begin{array}{l}\text { Cerebral } \\
\text { cortex }\end{array}$ & $\begin{array}{l}\text { Respiratory } \\
\text { epithelium }\end{array}$ \\
\hline$K_{m}(\mu \mathrm{M})$ & $2.0 \pm 0.3$ & $1.4 \pm 0.1$ & $39.6 \pm 4.8$ & $3.7 \pm 1.3$ \\
$V_{\max }(\mathrm{nmol} / \mathrm{mg} / \mathrm{min})$ & $4.9 \pm 0.2$ & $15.8 \pm 2.8$ & $66.2 \pm 10.4$ & $1.7 \pm 0.6$ \\
Hill coefficient & $0.51 \pm 0.06$ & $0.42 \pm 0.10$ & $0.89 \pm 0.04$ & $0.44 \pm 0.10$ \\
$V($ at $1 \mu \mathrm{M} \mathrm{cAMP})$ & $1.5 \pm 0.1$ & $6.6 \pm 1.1$ & $1.6 \pm 0.2$ & $0.35 \pm 0.11$
\end{tabular}

PDE activity was compared in olfactory cilia and homogenates of olfactory mucosa, respiratory epithelium, and cerebral cortex. PDE assay was performed with $100 \mu \mathrm{M} \mathrm{Ca}{ }^{2+}$ and $50 \mathrm{nM}$ calmodulin as described in Materials and Methods. $K$ and $V_{\max }$ were calculated from Eadie-Hofstee plots based on the best-fit lines and represent the average values determined for a mixture of PDE isozymes. Hill coefficients were calculated from plot of $\log (V /(1-V))$ versus $\log [c A M P]$. Results are expressed as mean \pm SEM of three independent experiments performed in duplicate. 


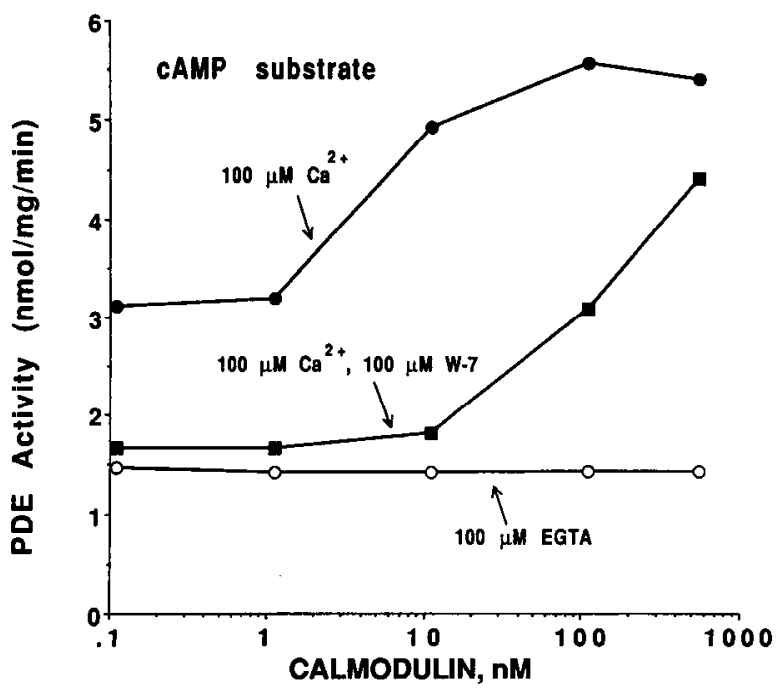

Figure 3. PDE activity in cilia as a function of calmodulin concentration. PDE activity was assayed using $1 \mu \mathrm{M}$ cAMP as substrate. Calmodulin concentration was varied from $10^{-10} \mathrm{M}$ to $5 \times 10^{-7} \mathrm{M}$. Three conditions were compared: $100 \mu \mathrm{M}$ EGTA (open circles), $100 \mu \mathrm{M} \mathrm{Ca}{ }^{2+}$ (solid circles), or $100 \mu \mathrm{M} \mathrm{Ca}{ }^{2+}$ in the presence of $100 \mu \mathrm{M} \mathrm{W}-7$ (solid squares). This experiment is representative of two experiments performed in duplicate.

tent with competition between calmodulin and $\mathrm{W}-7 . \mathrm{Ca}^{2+}$ potently stimulated ciliary PDE activity, as shown using $1 \mu \mathbf{M}$ cAMP (Fig. 4). Free $\mathrm{Ca}^{2+}$ was measured in the presence of 200 $\mu \mathrm{M}$ EGTA and $50 \mathrm{nM}$ calmodulin with increasing concentrations of added $\mathrm{CaCl}_{2}$. Stimulation was half-maximal at about $1 \mu \mathrm{M}$ $\mathrm{Ca}^{2+}$ and saturated by approximately $100 \mu \mathrm{M} \mathrm{Ca}{ }^{2+}$.

To examine an association of olfactory mucosal PDE with olfactory neurons, we evaluated the effects of olfactory bulbectomy (Table 3). The efficacy of bulbectomy was ensured in sevcral ways. When the site of bulbectomy was directly inspected, only about $10 \%$ of olfactory bulb tissue remained. Histochemical examination of the olfactory epithelium revealed a marked depletion of olfactory neurons (see Fig. 6). Moreover, staining for olfactory marker protein (Margolis et al., 1974) was depleted about $80 \%$ (data not shown).

In olfactory epithelium from control animals, about $75 \%$ of total PDE activity measured in the presence of EGTA occurred in the soluble supernatant fraction, with $13 \%$ each in the mi-

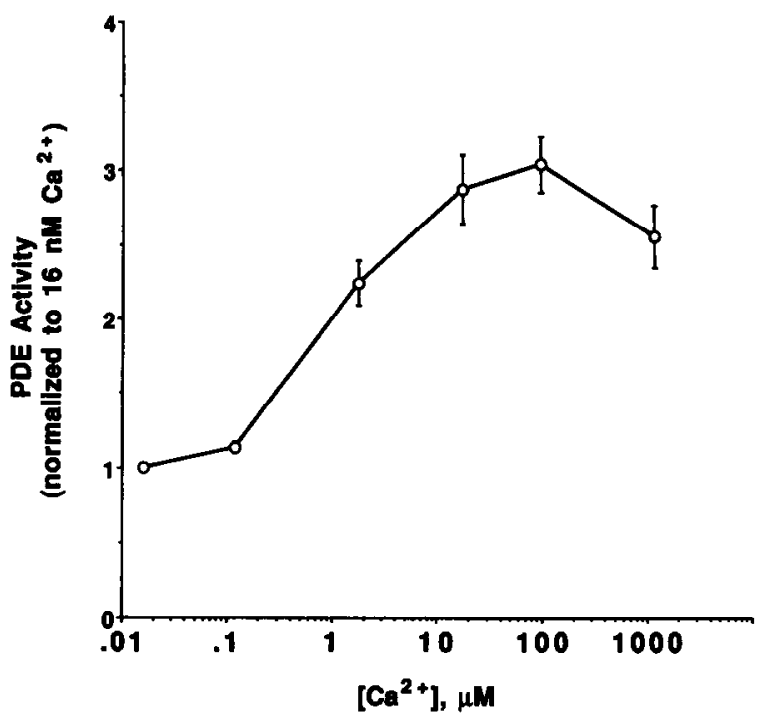

Figure 4. PDE activity in cilia as a function of free $\mathrm{Ca}^{2+}$ concentration. $\mathrm{PDE}$ activity and $\mathrm{Ca}^{2+}$ concentrations were measured in the presence of $1 \mu \mathrm{M}$ cAMP and $50 \mathrm{nM}$ calmodulin. Free $\mathrm{Ca}^{2+}$ concentrations were determined using a conductivity meter and $\mathrm{Ca}^{2+}$ electrode. $\mathrm{Ca}^{2+}$ at $10^{-7}$ $M$ to $10^{-3} \mathrm{M}$ was prepared in the presence of $200 \mu \mathrm{M}$ EGTA with increasing concentrations of $\mathrm{CaCl}_{2}$ added as appropriate. $\mathrm{Ca}^{2+}$ at $1.8 \times$ $10^{-8} \mathrm{M}$ was prepared in the presence of $2 \mathrm{mM}$ EGTA. PDE activity is expressed in units of activity normalized to activity at $16 \mathrm{nM} \mathrm{Ca}^{2+}$. Data are means of three experiments performed in triplicate, \pm SEM.

crosomal $\left(\mathrm{P}_{3}\right)$ and denser particulate $\left(\mathrm{P}_{2}\right)$ fractions. Stimulation by $\mathrm{Ca}^{2+}$ and calmodulin was greatest in the $\mathbf{P}_{3}$ and $\mathbf{P}_{2}$ fractions. In the presence of $\mathrm{Ca}^{2+}$ and calmodulin, only 50\% of PDE activity was soluble, while $20 \%-25 \%$ occurred in each of the $P_{3}$ and $\mathrm{P}_{2}$ fractions. Following bulbectomy, $\mathrm{PDE}$ specific activity was depleted about $90 \%$ and $80 \%$ in the $P_{2}$ and $P_{3}$ fractions, respectively, while soluble specific activity was diminished only about $50 \%$. Total soluble activity was not significantly changed following bulbectomy. Depletion was greatest for $\mathrm{Ca}^{2+} / \mathrm{calmo-}$ dulin stimulated activity but still pronounced when measured in the presence of EGTA (Table 3).

\section{Immunohistochemical localization of CAM-PDE in olfactory mucosa}

We have conducted immunohistochemical studies utilizing an MAb with high-affinity for CAM-PDE of rat brain and 100 times

Table 3. Subcellular distribution of PDE activity in control and bulbectomized olfactory mucosa

\begin{tabular}{|c|c|c|c|c|c|c|}
\hline & \multicolumn{2}{|c|}{ Dense particulate $\left(\mathrm{P}_{2}\right)$} & \multicolumn{2}{|c|}{ Microsomal $\left(\mathbf{P}_{3}\right)$} & \multicolumn{2}{|l|}{ Soluble $\left(\mathrm{S}_{3}\right)$} \\
\hline & $\begin{array}{l}\text { Specific } \\
\text { activity } \\
(\mathrm{nmol} / \mathrm{mg} / \mathrm{min}\end{array}$ & $\begin{array}{l}\text { Units } \\
\text { (pmol/min) }\end{array}$ & $\begin{array}{l}\text { Specific } \\
\text { activity } \\
\text { (nmol } / \mathrm{mg} / \mathrm{min} \text { ) }\end{array}$ & $\begin{array}{l}\text { Units } \\
(\mathrm{pmol} / \mathrm{min})\end{array}$ & $\begin{array}{l}\text { Specific } \\
\text { activity } \\
(\mathrm{nmol} / \mathrm{mg} / \mathrm{min})\end{array}$ & $\begin{array}{l}\text { Units } \\
\text { (pmol/min) }\end{array}$ \\
\hline \multicolumn{7}{|l|}{ Control } \\
\hline $\mathrm{Ca}^{2+}$ & $1.78 \pm 0.35$ & $182 \pm 62$ & $1.16 \pm 0.87$ & $148 \pm 45$ & $0.96 \pm 0.39$ & $368 \pm 83$ \\
\hline EGTA & $0.46 \pm 0.02$ & $48 \pm 11$ & $0.41 \pm 0.24$ & $38 \pm 8$ & $0.65 \pm 0.32$ & $222 \pm 46$ \\
\hline \multicolumn{7}{|c|}{ Bulbectomized } \\
\hline $\mathrm{Ca}^{2+}$ & $0.15 \pm 0.02$ & $36 \pm 8$ & $0.15 \pm 0.07$ & $51 \pm 20$ & $0.52 \pm 0.28$ & $404 \pm 150$ \\
\hline EGTA & $0.08 \pm 0.02$ & $19 \pm 3$ & $0.09 \pm 0.04$ & $28 \pm 11$ & $0.18 \pm 0.06$ & $172 \pm 71$ \\
\hline
\end{tabular}

Bulbectomy and subcellular fractionation were performed as described in Materials and Methods. PDE assays were performed using $1 \mu \mathrm{M}$ cAMP in the presence of $50 \mathrm{nM}$ calmodulin and $100 \mu \mathrm{M} \mathrm{Ca}{ }^{2+}$ or $2 \mathrm{~mm}$ EGTA. Results are expressed as mean \pm SEM of three to four independent experiments performed in duplicate. Units of activity (pmol/min) in individual fractions were calculated from the specific activity and protein concentration in the given fractions. 

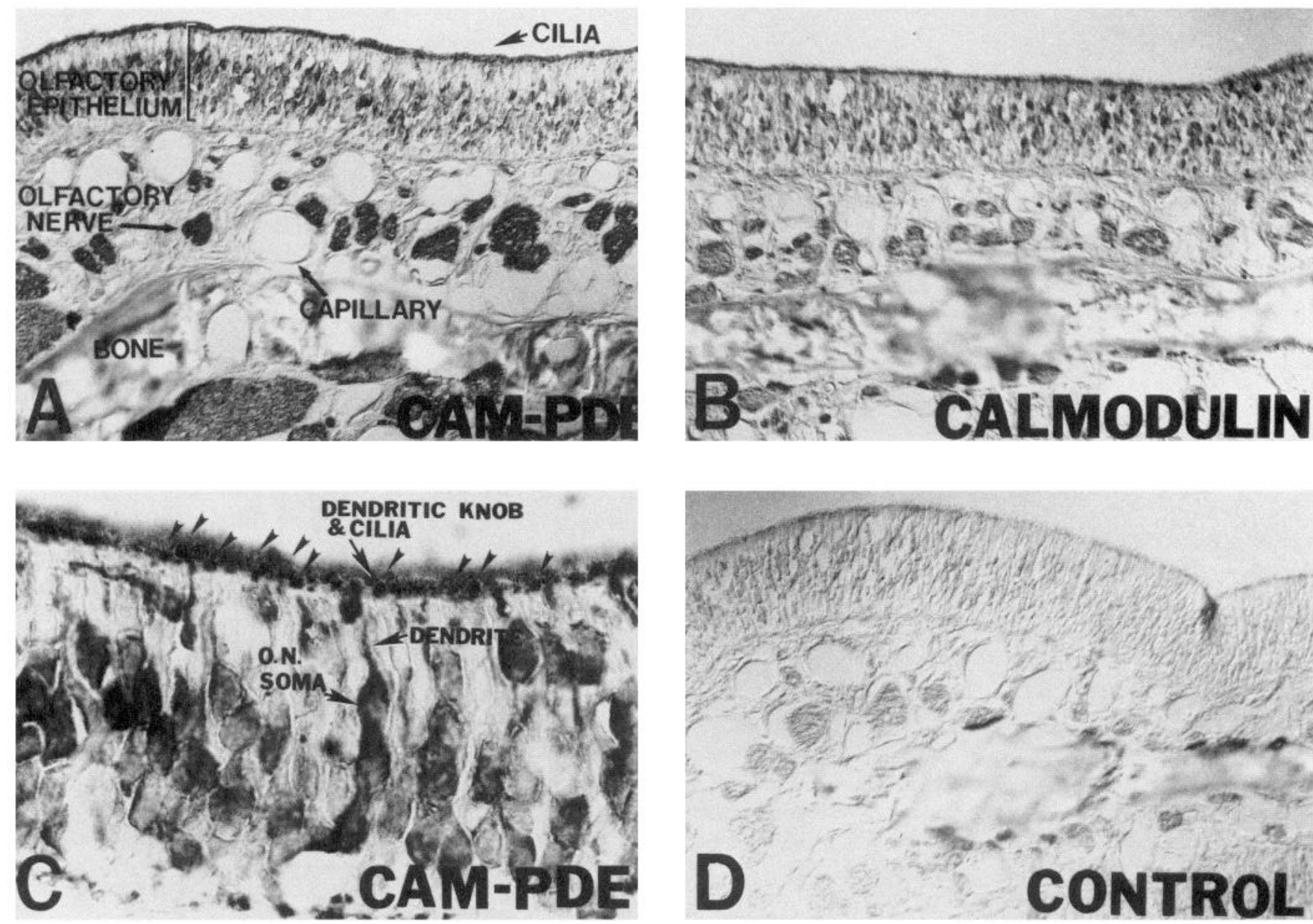

Figure 5. Immunohistochemical localization of CAM-PDE in olfactory turbinates. Immunohistochemistry was performed as described in Materials and Methods. A, Immunoreactivity (IR) of MAb ACC-A4C3 against CAM-PDE is shown at $200 \times$ magnification, using Nomarski optics. IR is present in olfactory neuron cell bodies, dendritic knobs, cilia, and olfactory nerve bundles. No IR is present in either the sustentacular or basal cell layers. $B$, IR of sheep polyclonal antibody against calmodulin is shown at $200 \times$ magnification, using Nomarski optics. IR is present in olfactory neuron cell bodies, dendritic knobs, and nerve bundles, and to a lesser extent in the ciliary layer. $C$, Oil immersion phase image (1000x magnification) of CAM-PDE IR shows dense staining in dendritic knobs and cilia as well as soma. Arrowheads indicate dendritic knobs and cilia exhibiting positive IR. O.N., olfactory neuron. $D$, Control photomicrograph at $200 \times$ magnification, using Nomarski optics, shows very little IR. MAb ACC-A4C3 against CAM-PDE was preabsorbed with a fivefold molar excess purified CAM-PDE from bovine brain (61 kDa and $63 \mathrm{kDa}$ forms) for $1 \mathrm{hr}$ prior to immunostaining. Almost all IR was eliminated.

less affinity for calmodulin itself or other calmodulin-binding proteins (Hansen and Beavo, 1986). No staining is apparent with several ascites control preparations. The specificity of the antibody was also confirmed by its ability to immunoprecipitate $\mathrm{Ca}^{2+} /$ calmodulin-activated PDE activity (data not shown).

At low magnification, staining for CAM-PDE is most prominent in the ciliary layer but is also apparent in neuronal cell bodies and axon bundles (Fig. $5 A$ ). At higher power, we can determine that staining of the ciliary layer is due to immunoreactivity within the cilia as well as the dendritic knobs (Fig. $5 C$ ). Staining with an antibody that specifically recognizes calmodulin (Dedman et al., 1978) also shows immunoreactivity in cell bodies, axon bundles, and dendritic knobs; however, staining in the ciliary layer is less pronounced (Fig. $5 B$ ). Specificity of the CAM-PDE antibody is demonstrated by preabsorption with the $61 \mathrm{kDa}$ and $63 \mathrm{kDa}$ forms of bovine CAMPDE eliminating almost all staining (Fig. 5D). Antisera to the cGMP-inhibited and the retinal rod PDE enzymes gave no staining. Antiserum to the cGMP-stimulated PDE did not stain olfactory receptor neurons but specifically stained goblet cells.
We observed marked differences in olfactory epithelial staining between normal and bulbectomized sides (Fig. 6). The intense staining of the ciliary layer in the intact side (Fig. $6 \mathrm{~A}$ ) is absent in the bulbectomized side (Fig. 6B). By contrast, in the bulbectomized side, neuronal cell bodies are stained to a greater extent than in the intact side, presumably reflecting cells surviving bulbectomy or regenerating cells. The dendritic processes of the stained cells in the bulbectomized side tend not to reach the ciliary layer, suggesting that these represent regenerating olfactory neuronal cells. CAM-PDE immunoreactivity appears to be selective for olfactory neurons. By comparison, respiratory epithelial cells and respiratory cilia are not stained by this antibody (Fig. 7).

CAM-PDE has been previously localized by immunocytochemistry in the brain (Kincaid et al., 1987). To ensure that our antibody selectively recognizes PDE, we conducted immunocytochemical examination in the cerebellum (data not shown). As observed previously by Balaban et al. (1989), CAM-PDE staining was highly localized to Purkinje cells and their processes. Calmodulin staining was also greatest in Purkinje cells 

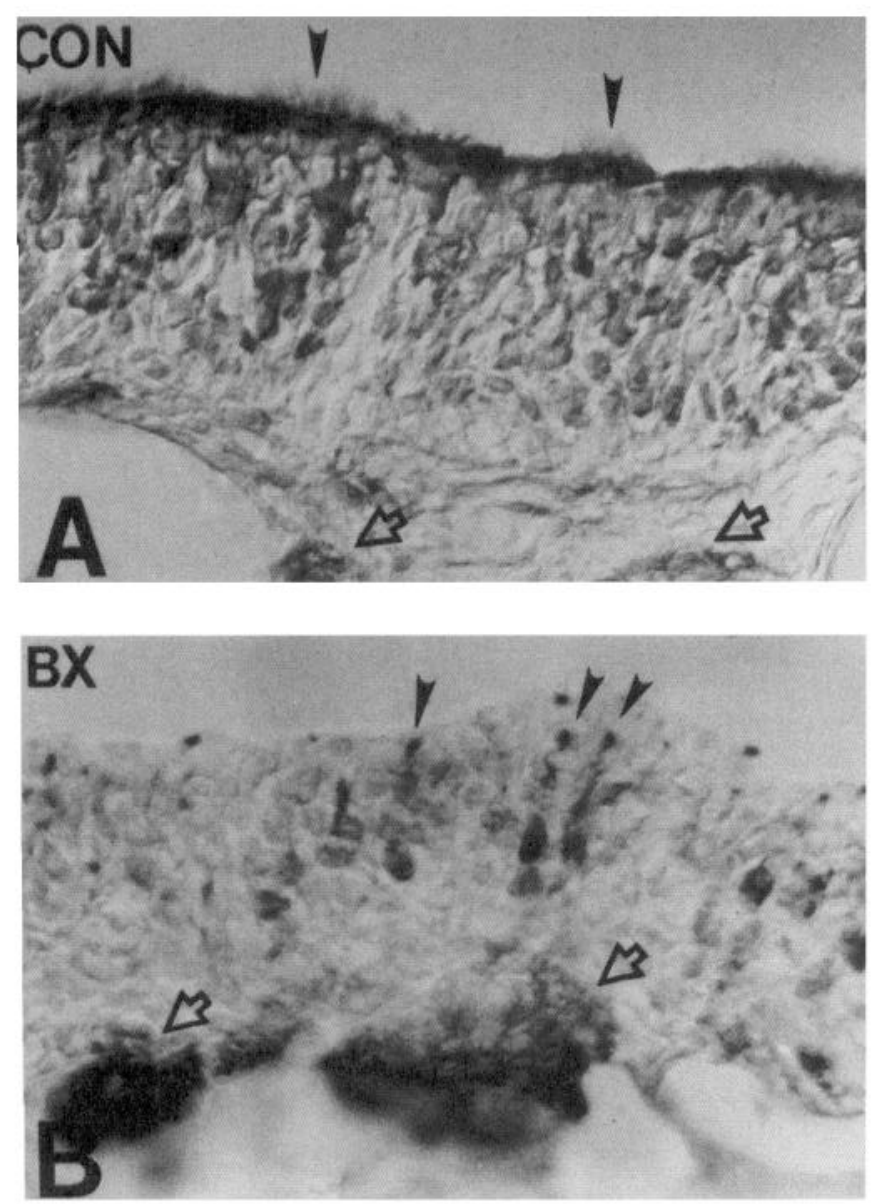

Figure 6. Comparison of immunohistochemical localization of CAMPDE in control and bulbectomized turbinates. Bulbectomy and immunohistochemistry were performed as described in Materials and Methods. CAM-PDE immunoreactivity was visualized by Nomarski optics and magnified $620 \times$. A, Control epithelium. Solid arrowheads indicate positive immunoreactivity in clumps of cilia, while open arrows show immunoreactivity in olfactory nerve bundles. $B$, Bulbectomized epithelium. Cilia cannot be easily seen. Solid arrowheads indicate positive immunoreactivity in dendritic knobs that have not yet reached the epithelial surface. Open arrows show immunoreactivity in olfactory nerve bundles.

but appeared to a lesser extent in granule cells. Preabsorption with PDE eliminated staining by the CAM-PDE antibody.

\section{Discussion}

The principal findings of this study are that within olfactory mucosa a CAM-PDE appears to be the major PDE and is selectively localized to olfactory neurons. Our biochemical assays suggest that olfactory CAM-PDE may be a novel isoform of this enzyme and the predominant form in this tissue. Moreover, we observed negligible staining of rat olfactory mucosa with antisera to the cGMP-activated, the cGMP-inhibited, and the retinal rod PDE enzymes.

Biochemical properties of the olfactory epithelial CAM-PDE are also consistent with prominent activity under physiological concentrations. The enzyme is stimulated by physiologic submicromolar concentrations of $\mathrm{Ca}^{2+}$. Also, the olfactory epithelial enzyme has higher affinity for cAMP than the brain enzyme. We have calculated that the physiological cAMP concentration in olfactory neurons is about $10^{-6} \mathrm{M}$, based on measurements

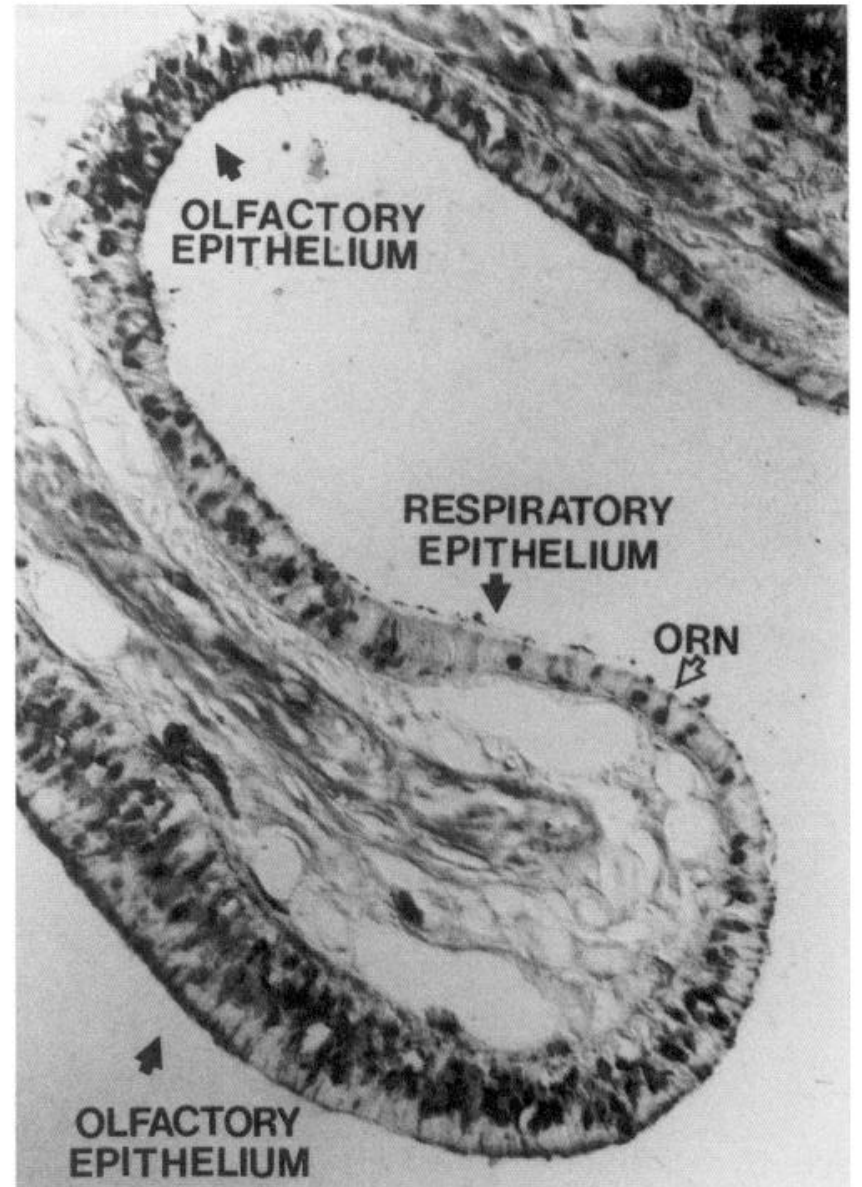

Figure 7. Immunohistochemical localization of CAM-PDE at region of overlap between olfactory and respiratory epithelium. Immunohistochemistry was performed as described in Materials and Methods. CAM-PDE immunoreactivity was visualized by Nomarski optics and is shown at $250 \times$ magnification. Only olfactory receptor neurons exhibit immunoreactivity to MAb ACC-A4C3 against CAM-PDE. Respiratory epithelial cells and respiratory cilia remain unstained. Areas of olfactory epithelium and respiratory epithelium are marked by arrows. The open arrow indicates an isolated olfactory receptor neuron $(O R N)$.

of total endogenous cAMP in cultured olfactory receptor neurons and employing an assumption that tissue is approximately $10 \%$ protein. These levels are similar to those in liver and brain (Gilman, 1970). Nakamura and Gold (1987) detected two types of cyclic nucleotide-gated channels in olfactory receptor neurons, with $K_{1 / 2}$ values of $10^{-6}$ and $10^{-5} \mathrm{M}$. Given such a highly active conductance, odorant stimulation mediated via elevation of cyclic nucleotides would require basal levels of cAMP and cGMP to be approximately $10^{-7} \mathbf{M}$ or less. Such a system might also require the presence of a high-affinity PDE. Brain CAMPDE is one of the most active in the body (Butcher and Sutherland, 1962). At the low micromolar physiological concentrations of cAMP, enzyme activity in olfactory epithelium is four to five times greater than in brain. In most mammalian tissues, the predominant CAM-PDE is the low-affinity enzyme (Beavo, 1988 ) so that olfactory epithelium is notable in having a CAMPDE with apparent high affinity for cAMP.

The Hill coefficient for PDE activity is almost 0.9 in brain, but $0.4-0.5$ in cilia, olfactory mucosa, and respiratory epithe- 
lium. These low Hill coefficients most likely reflect the presence of multiple populations of PDE with differing affinities for cAMP rather than negative cooperativity of the enzyme. Rolipram and Ro20-1724 are selective inhibitors of a PDE with high affinity for cAMP and not linked to $\mathrm{Ca}^{2+}$ and calmodulin (Schwabe et al., 1976; Wachtel, 1983; Kaulen et al., 1989; Nemoz et al., 1989). In the absence of $\mathrm{Ca}^{2+}$, olfactory mucosal PDE is inhibited about $60 \%$ by rolipram, but only about $20 \%$ in the presence of $\mathrm{Ca}^{2+}$. Our assays most likely are detecting a mixture of at least two enzymes, with the rolipram-sensitive PDE being dominant in the abscnce of $\mathrm{Ca}^{2+}$ and the CAM-PDE becoming the predominant form in response to $\mathrm{Ca}^{2+}$ stimulation.

Our immunocytochemical studies reveal a selective localization of CAM-PDE to olfactory neurons, with strong immunoreactivity in the olfactory cilia. These observations further support a role for CAM-PDE in olfactory transduction, as all the major elements of olfactory transduction, such as a selective G-protein (Jones and Reed, 1989), ulfactory-specific adenylyl cyclase (Sklar et al., 1986; Bakalyar and Reed, 1990), and a cyclic nucleotide-gated ion channel (Lowe and Gold, 1991), are localized to these cilia. Calmodulin mRNA is also expressed in olfactory receptor neurons (Biffo et al., 1991).

The $\mathrm{Ca}^{2+}$ sensitivity of olfactory neuronal PDE fits with a variety of evidence supporting a role for $\mathrm{Ca}^{2+}$ in olfaction. Odorants potently and rapidly stimulate the formation of $\mathrm{IP}_{3}$ in olfactory cilia (Boeckhoff et al., 1990; Breer et al., 1990) and primary olfactory ncuronal cultures (Wood et al., 1990). IP 3 acts by releasing $\mathrm{Ca}^{2+}$. $\mathrm{IP}_{3}$ gates plasma membrane $\mathrm{Ca}^{2+}$ channels in human T-lymphocytes (Kuno and Gardner, 1987) and catfish olfactory cilia (Restrepo et al., 1990). In brain and some peripheral tissues, $\mathrm{IP}_{3}$ receptors are localized to endoplasmic reticulum, providing the principal source of intracellular $\mathrm{Ca}^{2+}$ released by $\mathrm{IP}_{3}$ (Ross et al., 1990). However, in lymphocytes (A. Khan, J. Steiner, and S. H. Snyder, unpublished observations) and olfactory cilia (A. Cunningham, D. Ryugo, R. Reed, A. Sharp, G. Ronnett, and S. H. Snyder, unpublished observations), immunohistochemical studies by confocal and electron microscopy have localized $\mathrm{IP}_{3}$ receptor to the plasma membrane, suggesting that in olfaction $\mathrm{IP}_{3}$ regulates $\mathrm{Ca}^{2+}$ entry into the cilium. In primary olfactory neuronal cultures, phosphoinositide turnover is enhanced by odorants more rapidly than adenylyl cyclase, and the adenylyl cyclase of these cultures is absolutely dependent upon $\mathrm{Ca}^{2+}$ for activity (Wood et al., 1990; Ronnett et al., 1991b). Ciliary adenylyl cyclase is also potently stimulated by $\mathrm{Ca}^{2+}$ and calmodulin (Anholt and Rivers, 1990). While odorant enhancement of adenylyl cyclase in olfactory cilia has been reported with media containing low $\mathrm{Ca}^{2+}$ concentration, these cilia were first exposed to high levels of $\mathrm{Ca}^{2+}$ (Boeckhoff et al., 1990). These findings suggest that odorants initially stimulate $\mathrm{IP}_{3}$ formation, with the released $\mathrm{Ca}^{2+}$ then activating adenylyl cyclase. The prominence of CAM-PDE in olfactory cilia suggests that CAM-PDE is activated at the same time to degrade the newly formed cAMP. Coordinated control of adenylyl cyclase and phosphodiesterase activity has been previously observed in guinea pig brain (Piascik et al., 1980). Such a model accords with the rapid decline in levels of cAMP formed following odorant stimulation (Boeckhoff et al., 1990; Ronnett et al., 1991b).

\section{References}

Anholt RRH, Rivers AM (1990) Olfactory transduction: cross-talk between second-messenger systems. Biochemistry 29:4049-4054.
Bakalyar HA, Reed RR (1990) Identification of a specialized adenylyl cyclase that may mediate odorant detection. Science 250:1403-1406.

Balaban CD, Billingsley ML, Kincaid RL (1989) Evidence for transsynaptic regulation of calmodulin-dependent cyclic nucleotide phosphodiesterase in cerebellar Purkinje cells. J Neurosci 9:2374-2381.

Bauer AC, Schwabe U (1980) An improved assay of cyclic 3',5'-nucleotide phosphodiesterases with QAE-Sephadex columns. Naunyn Schmiedebergs Arch Pharmacol 311:193-198.

Beavo JA (1988) Multiple isozymes of cyclic nucleotide phosphodiesterase. Adv Second Messenger Phosphoprotein Res 22:1-38.

Beavo JA, Hardman JG, Sutherland EW (1971) Stimulation of adenosine $3^{\prime}, 5^{\prime}$-monophosphate hydrolysis by guanosine $3^{\prime}, 5^{\prime}$-monophosphate. J Biol Chem 246:3841-3846.

Biffo S, Goren T, Khew-Goodall YS, Miara J, Margolis FL (1991) Expression of calmodulin mRNA in rat olfactory neuroepithelium. Mol Brain Res 10:13-21.

Boekhoff I, Tareilus E, Strotmann J, Breer H (1990) Rapid activation of alternative second messenger pathways in olfactory cilia from rats by different odorants. EMBO J 9:2453-2458.

Breer H, Boekhoff I, Tareilus E (1990) Rapid kinetics of second messenger formation in olfactory transduction. Nature 345:65-68.

Butcher RW, Sutherland EW (1962) Adenosine 3',5'-phosphate in biological materials. J Biol Chem 237:1244-1250.

Dedman JR, Welsh MJ, Means AR (1978) $\mathrm{Ca}^{2+}$-dependent regulatorproduction and characterization of a monospecific antibody. J Biol Chem 253:7515-7521.

Epstein PM, Strada SJ, Sarada K, Thompson WJ (1982) Catalytic and kinetic properties of purified high-affinity cyclic AMP phosphodiesterase from dog kidney. Arch Biochem Biophys 218:119-133.

Firestein S, Werblin F (1989) Odor-induced membrane currents in vertebrate-olfactory receptor neurons. Science 244:79-82.

Firestein S, Darrow B, Shepherd GM (1991) Activation of the sensory current in salamander olfactory receptor neurons depends on a $G$ protein-mediated cAMP second messenger system. Neuron 6:825835

Frings S, Lindemann B (1991) Current recording from sensory cilia of olfactory receptor cells in situ. J Gen Physiol 97:1-16.

Gilman AG (1970) A protein binding assay for adenosine $3^{\prime}, 5^{\prime}$-cyclic monophosphate. Proc Natl Acad Sci USA 67:305-312.

Hansen RS, Beavo J (1986) Differential recognition of calmodulinenzyme complexes by a conformation-specific anti-calmodulin monoclonal antibody. J Biol Chem 261:14636-14645.

Harrison SA, Reifsnyder DA, Gallis B, Cadd GG, Beavo JA (1986) Isolation and characterization of bovine cardiac muscle cGMP-inhibited phosphodiesterase: a receptor for new cardiotonic drugs. Mol Pharmacol 29:506-514.

Jones DT, Reed RR (1989) $G_{\text {olf }}$ an olfactory neuron-specific $G$ protein involved in odorant signal transduction. Science 244:790-795.

Kaulen P, Bruning G, Schneider HH, Sarter M, Baumgarten HG (1989) Autoradiographic mapping of a selective cyclic adenosine monophosphate phosphodiesterase in rat brain with the antidepressant [ ${ }^{3}$ H]rolipram. Brain Res 503:229-245.

Kincaid RL, Manganiello VC (1988) Assay of cyclic nucleotide phosphodiesterase using radiolabeled and fluorescent substrates. Methods Enzymol 159:457-470.

Kincaid RL, Balaban CD, Billingsley MV (1987) Differential localization of calmodulin-dependent enzymes in rat brain: evidence for sclcctive expression of cyclic nucleotide phosphodiesterase in specific neurons. Proc Natl Acad Sci USA 84:1118-1122.

Kuno M, Gardner P (1987) $\mathrm{Ca}^{2+}$ channels activated by inositol 1,4,5trisphosphate in plasma membrane of human T-lymphocytes. Nature 326:301-304.

Lowe G, Gold GH (1991) The spatial distributions of odorant sensitivity and odorant-induced currents in salamander olfactory receptor cells. J Physiol (Lond) 442:147-168.

Margolis FL (1977) Biochemical studies of the primary olfactory pathway. In: Society for Neuroscience Symposia, Vol III, Aspects of behavioral neurobiology (Ferrendelli JA, ed), pp 167-188. Bethesda, MD: Society for Neuroscience.

Margolis FL, Roberts N, Ferriero D, Feldman J (1974) Denervation in the primary olfactory pathway of mice: biochemical and morphological effects. Brain Res 81:469-483.

Martins TJ, Mumby MC, Beavo JA (1982) Purification and characterization of a cyclic GMP-stimulated cyclic nucleotide phosphodiesterase from bovine tissues. J Biol Chem 257:1973-1979. 
Miki N, Keirns JJ, Marcus FR, Freeman J, Bitensky M (1973) Regulation of cyclic nucleotide concentrations in photoreceptors: an ATP. dependent stimulation of cyclic nucleotide phosphodiesterase by light. Proc Natl Acad Sci USA 70:3820-3824.

Nakamura T, Gold GH (1987) A cyclic nucleotide-gated conductance in olfactory receptor cilia. Nature 325:442-444.

Nemoz G, Moueqqit M, Prigent A, Pacheco H (1989) Isolation of similar rolipram-inhibitable cyclic-AMP-specific phosphodiesterases from rat brain and heart. Eur J Biochem 184:511-520.

Nicholson CD, Jackman SA, Wilke R (1989) The ability of denbufylline to inhibit cyclic nucleotide phosphodiesterase and its affinity for adenosine receptors and the adenosine re-uptake site. Br J Pharmacol 97:889-897.

Pace U, Hanski E, Salomon Y, Lancet D (1985) Odorant-sensitive adenylate cyclase may mediate olfactory reception. Nature 316:255258

Piascik MT, Wisler PL, Johnson CL, Potter JD (1980) Calcium dependent regulation of guinea pig brain adenylate cyclase. J Biol Chem 255:4176-4181.

Restrepo D, Miyamoto T, Bryant BP, Teeter JH (1990) Odor stimuli trigger influx of $\mathrm{Ca}^{2+}$ into olfactory neurons of the channel catish Science 249:1166-1168.

Ronnett GV, Hester LD, Snyder SH (1991a) Primary culture of neonatal rat olfactory neurons. J Neurosci 11:1243-1255.

Ronnett GV, Parfitt DJ, Hester LD, Snyder SH (1991b) Odorantsensitive adenylyl cyclase: rapid, potent activation and deactivation in primary olfactory neuronal cultures. Proc Natl Acad Sci USA 88 $2366-2369$.

Ross CA, Bredt DS, Snyder SH (1990) Messenger molecules in the cerebellum. Trends Neurosci 13:216-222.

Schwabe U, Miyake M, Ohga Y, Daly JW (1976) 4-(3-Cyclopentyloxy4-methoxyphenyl)-2-pyrrolidone (ZK 62711): a potent inhibitor of adenosine cyclic $3^{\prime}, 5^{\prime}$-monophosphate phosphodiesterases in homogenates and tissue slices from rat brain. Mol Pharmacol 12:900-910.
Sharma RK, Wang JH (1986) Regulation of cAMP concentration by calmodulin-dependent cyclic nucleotide phosphodiesterase. Biochem Cell Biol 64:1072-1080.

Simmons MA, Hartzell HC (1988) Role of phosphodiesterase in regulation of $\mathrm{Ca}^{2+}$ current in isolated cardiac myocytes. Mol Pharmacol 33:664-671.

Sklar PB, Anholt RRH, Snyder SH (1986) The odorant-sensitive adenylate cyclase of olfactory receptor cells. J Biol Chem 261:1553815543.

Teo TS, Wang JH (1973) Mechanism of activation of a cyclic adenosine $3^{\prime}: 5^{\prime}$-monophosphate phosphodiesterase from bovine heart by $\mathrm{Ca}^{2+}$ ions. J Biol Chem 248:5950-5955.

Thompson WJ, Brooker G, Appleman MM (1972) Assay of cyclic nucleotide phosphodiesterase with radioactive substrates. Methods Enzymol 34:205-212.

Thompson WJ, Epstein PM, Strada SJ (1979) Purification and characterization of high-affinity cyclic adenosine monophosphate phosphodiesterase from dog kidney. J Am Chem Soc 79:5228-5237.

Wachtel H (1983) Potential antidepressant activity of rolipram and other selective cyclic adenosine 3',5'-monophosphate phosphodiesterase inhibitors. Neuropharmacology 22:267-272.

Weber HW, Appleman MM (1982) Insulin-dependent and insulinindependent low $K_{m}$ cyclic AMP phosphodiesterase from rat adipose tissue. J Biol Chem 257:5339-5341.

Winegar BD, Rosick ER, Schafer R (1988) $\mathrm{Ca}^{2+}$ and olfactory transduction. Biochem Physiol 91A:309-315.

Wood SF, Ronnett GV, Snyder SH (1990) Activation of inositolphosphate metabolism in primary olfactory cell cultures. Chem Senses 15:655.

Yamamoto T, Manganiello VC, Vaughan M (1983) Purification and characterization of cyclic GMP-stimulated cycle nucleotide phosphodiesterase from calf liver. J Biol Chem 258:12526-12533. 